\title{
Rates and regulation of anaerobic ammonium oxidation and denitrification in the Black Sea
}

Marlene M. Jensen 1

Nordic Center for Earth Evolution, Institute of Biology, University of Southern Denmark, Campusvej 55, 5230 Odense M, Denmark

\section{Marcel M. M. Kuypers and Gaute Lavik}

Max Planck Institute for Marine Microbiology, Nutrient Group, Celsiusstr. 1, 28359 Bremen, Germany

\section{Bo Thamdrup ${ }^{2}$}

Nordic Center for Earth Evolution, Institute of Biology, University of Southern Denmark, Campusvej 55, 5230 Odense M, Denmark

\begin{abstract}
We performed incubation experiments with ${ }^{15} \mathrm{~N}$-labeled nitrogen compounds to investigate the vertical distribution of pathways of $\mathrm{N}_{2}$ production through the suboxic zone of the central Black Sea and the impact of oxygen and sulfide on the anammox process. Anammox rates increased with depth through the upper suboxic zone and reached a maximum of $\sim 11 \mathrm{nmol} \mathrm{N}_{2} \mathrm{~L}^{-1} \mathrm{~d}^{-1}$ at the sharp interface between nitrate and ammonium, below which rates decreased toward the depth of sulfide accumulation. Heterotrophic denitrification was not detected, and therefore anammox was the prevailing sink for fixed nitrogen in the central Black Sea. In incubations with low oxygen concentrations, anammox activity was only partially inhibited, with a decrease in anammox rates to $\sim 70 \%$ and $50 \%$ of the anoxic level at $\sim 3.5$ and $\sim 8 \mu \mathrm{mol} \mathrm{L}-1 \mathrm{O}_{2}$, respectively, and complete inhibition at $\sim 13.5 \mu \mathrm{mol} \mathrm{L}-1 \mathrm{O}_{2}$. Thus, the anammox process is not constrained to anoxic marine waters. This increases the volume of the major open-ocean oxygen-deficient zones, where anammox is potentially active, which has important implications for the contribution of anammox to the marine nitrogen cycle. We observed an inhibitory effect of micromolar sulfide concentrations on anammox activity, indicating that the vertical and likely horizontal distribution of active anammox bacteria is constrained to nonsulfidic water layers, which may explain the absence of the process in sulfidic basins with no suboxic zone.
\end{abstract}

The discovery of anaerobic ammonium oxidation (anammox) in wastewater treatment systems (Mulder et al. 1995) and natural aquatic environments (Thamdrup and Dalsgaard 2002) resolved the mystery of ammonium deficiency in anoxic waters and challenged the preeminence of microbial denitrification as the only significant pathway for the removal of fixed nitrogen in the oceans (Devol 2003; Dalsgaard et al. 2005; Kuypers et al. 2006). Anaerobic ammonium oxidation with nitrite as an electron acceptor is mediated by a monophyletic group of bacteria that branches deeply in the phylum Planctomycetes (Strous et al. 1999; Schmid et al. 2003). The one-to-one coupling of

\footnotetext{
${ }^{1}$ Present address: Max Planck Institute for Marine Microbiology, Nutrient Group, Celsiusstr. 1, 28359 Bremen, Germany.

2 Corresponding author (bot@biology.sdu.dk).

Acknowledgments

We sincerely thank Carsten Schubert for organizing the research expedition and the captain and the crew on board the R/V Professor Vodyanitskiy for their assistance and enthusiastic support. We are grateful to Daniel McGinnis for generously providing CTD and oxygen data and $\mathrm{G}$. Klockgether for valuable analytical assistance. We thank two anonymous reviewers for their helpful evaluations of the manuscript. M.M.J. and B.T. were supported by the Danish National Research Council and the Danish National Research Foundation, M.M. M.K. and G.L. by the Max Planck Society.
}

nitrogen from ammonium and nitrite into gaseous $\mathrm{N}_{2}$, $\mathrm{NH}_{4}^{+}+\mathrm{NO}_{2}^{-} \rightarrow \mathrm{N}_{2}+2 \mathrm{H}_{2} \mathrm{O}$ (Van De Graaf et al. 1995), distinguishes the anammox process from denitrification, where two molecules of nitrate are combined to $\mathrm{N}_{2}$ in a stepwise pathway $\left(2 \mathrm{NO}_{3}^{-} \rightarrow 2 \mathrm{NO}_{2}^{-} \rightarrow 2 \mathrm{NO} \rightarrow \mathrm{N}_{2} \mathrm{O} \rightarrow\right.$ $\mathrm{N}_{2}$ ) (Zumft 1997).

Although a number of studies demonstrate the importance of anammox bacteria in the biological nitrogen cycle (Dalsgaard et al. 2005; Kuypers et al. 2006; Thamdrup et al. 2006), little is known about the main factors that control the distribution and magnitude of the process. Expectedly, oxygen is such an important regulator. Experimental work with enrichments of anammox bacteria from laboratory wastewater bioreactors has shown that anammox activity is reversibly inhibited by oxygen levels as low as $1 \mu \mathrm{mol} \mathrm{L} \mathrm{L}^{-1}$ (Strous et al. 1997), indicating that the process is active only under strictly anoxic conditions. Still, in the Benguela upwelling system off Namibia, the observed dominance of anammox was suggested to result from anammox being less sensitive than denitrification toward oxygen (Kuypers et al. 2005). There, anammox bacteria were immediately active when waters containing up to $9 \mu \mathrm{mol} \mathrm{L}-1$ of oxygen in situ were incubated under anoxic conditions, while denitrification remained undetectable. These observations raise the question whether anammox could indeed be active at low oxygen levels in the oceans. The sensitivity of anammox bacteria toward oxygen is an important issue for un- 
derstanding the role of anammox in the nitrogen cycle. If anammox is active at low oxygen levels, the ocean area affected by the process could be much larger than previously expected (Dalsgaard et al. 2003; Devol 2003). In this case, the water volume may exceed the volume affected by denitrification, as the latter process appears restricted to waters where oxygen is not detectable by standard analysis (Codispoti et al. 2001).

Several lines of evidence suggest that hydrogen sulfide may also have a regulatory effect on anammox in marine environments. Thus, the sulfidic interface of euxinic basins such as the Mariager Fjord (Denmark) is characterized by the absence of anammox, while denitrification is highly active (Jensen 2006; Kuypers et al. 2006). In the anoxic basin of Golfo Dulce (Costa Rica), Dalsgaard and coworkers (2003) found that the relative importance of anammox in total $\mathrm{N}_{2}$ production decreased from the nitrate-rich zone into the weakly sulfidic bottom layers. The authors argued that anammox could be directly inhibited by sulfide. Competitive inhibition was suggested as an alternative explanation, as sulfide-based denitrification might be stimulated. However, experimental verification of the effects of sulfide on marine anammox is lacking.

Recent genomic and ${ }^{15} \mathrm{~N}$-labeling experimental studies have shown that anammox bacteria have a more versatile metabolism than previously assumed (Güven et al. 2005; Strous et al. 2006; Kartal et al. 2007b). Cultured anammox bacteria were shown to use simple organic acids to reduce nitrate to ammonium with nitrite as an intermediate (Kartal et al. 2007a). Support for dissimilatory nitrate reduction to ammonium was additionally found in samples from the Benguela upwelling system, where anammox bacteria were active, indicating that this process may occur in natural environments (Kuypers et al. 2005; Kartal et al. 2007a). Knowledge of such additional pathways is important both for our understanding of the nitrogen cycle and for interpreting results of ${ }^{15} \mathrm{~N}$-labeling experiments.

The Black Sea represents a unique and excellent site for investigations on the effects of oxygen as well as sulfide on anammox activity. A distinguishing feature of the Black Sea is the $\sim 20-50$-m-thick suboxic zone, in which oxygen concentrations are $<10 \mu \mathrm{mol} \mathrm{L}-1$ and sulfide is undetectable (Murray et al. 1989, 1995). The exact vertical zonation of oxygen and sulfide varies in time and space (Sorokin 2002), and especially temporal fluctuations of oxygen at the upper boundary of the suboxic zone have been reported (Murray and Yakushev 2006; Lam et al. 2007). Massive lateral intrusions of oxygen-enriched water of the Bosporus plume into the suboxic zone have been observed as far as $200 \mathrm{~km}$ into the western Black Sea (Konovalov et al. 2003). The suboxic zone contains a pronounced nitrate peak, and there is a sharp interface between nitrate/nitrite and ammonium just above the depth where sulfide accumulates. These distributions were attributed to denitrification and anaerobic ammonium oxidation with nitrate as a potential oxidant (Murray et al. 1995). Subsequently, anammox bacteria were identified as the organisms responsible for ammonium consumption (Kuypers et al. 2003). Kuypers and coworkers (2003) combined measurements of potential ammonium-oxidizing activity with molecular biological methods and extraction of specific ladderane lipids, which are known only from these bacteria (Sinninghe Damsté et al. 2002). However, no direct quantification of anammox rates was obtained.

We here extend the story of anammox in the suboxic zone of the Black Sea by exploring rates and regulation of the process with the use of stable isotope tracer techniques. A series of experiments were conducted with three purposes: (1) to quantify anammox and denitrification rates throughout the suboxic zone, (2) to examine the influence of oxygen and sulfide on anammox activity, and (3) to examine the possible role of formate as an electron donor for the anammox process.

\section{Materials and methods}

Stations and sampling-For our investigation of rates and regulation of anammox, the water column was sampled at two locations during a cruise in August 2005 on the R/V Professor Vodyanitskiy (Fig. 1):

Sta. 1: $43^{\circ} 14^{\prime} \mathrm{N}, 34^{\circ} 00^{\prime} \mathrm{E}$, full water depth of $2,175 \mathrm{~m}$, the central Black Sea

Sta. 2: $44^{\circ} 09^{\prime} \mathrm{N}, 33^{\circ} 59^{\prime} \mathrm{E}$, full water depth of $\sim 300 \mathrm{~m}$, the Ukrainian continental slope south of Crimea

Water samples for chemical analysis and $15 \mathrm{~N}$-labeling experiments were obtained either by a CTD-pumpcast system, which allows for high-resolution profiles (Friederich and Codispoti 1987), or from Go-Flo bottles attached to a CTD-rosette system. During subsampling, the Go-Flo bottles were subjected to $\sim 10 \mathrm{kPa}$ overpressure of argon gas to minimize oxygen contamination. At Sta. 1, water samples were collected during the night between 17 and 18 August 2005 from depths of 85, 90, 95, 100, 105 and $110 \mathrm{~m}$ (Table 1). In addition, two depths at 100 and $105 \mathrm{~m}$ were sampled again on 19 August 2005. At Sta. 2, one depth $(115 \mathrm{~m})$ was sampled on 20 August 2005. Water was collected into $250-\mathrm{mL}$ or 2.5 -liter glass bottles with at least threefold overflow. Bottles were sealed immediately with butyl rubber stoppers, eliminating headspace and bubbles, and were stored on ice during sampling. The ${ }^{15} \mathrm{~N}$ incubation experiments were started immediately after sampling.

${ }^{15} \mathrm{~N}$ tracer experiments $-{ }^{15} \mathrm{~N}$ incubations were designed for four kinds of experiments (Table 1):

1. Distribution of anammox and denitrification activity through the suboxic zone

2. Sensitivity of anammox toward oxygen

3. Oxidation of formate by anammox bacteria

4. Effect of sulfide on anammox activity

All the ${ }^{15} \mathrm{~N}$ tracer incubations in these experiments were performed as described by Dalsgaard et al. (2003). Summarily, the $250-\mathrm{ml}$ or 2.5 -liter glass bottles were briefly opened, and $20 \mathrm{ml}$ of water were removed for measurements of initial $\mathrm{NO}_{3}^{-}, \mathrm{NO}_{2}^{-}$, and $\mathrm{NH}_{4}^{+}$concentrations. Various combinations of ${ }^{15} \mathrm{~N}$-labeled and unlabeled nitro- 


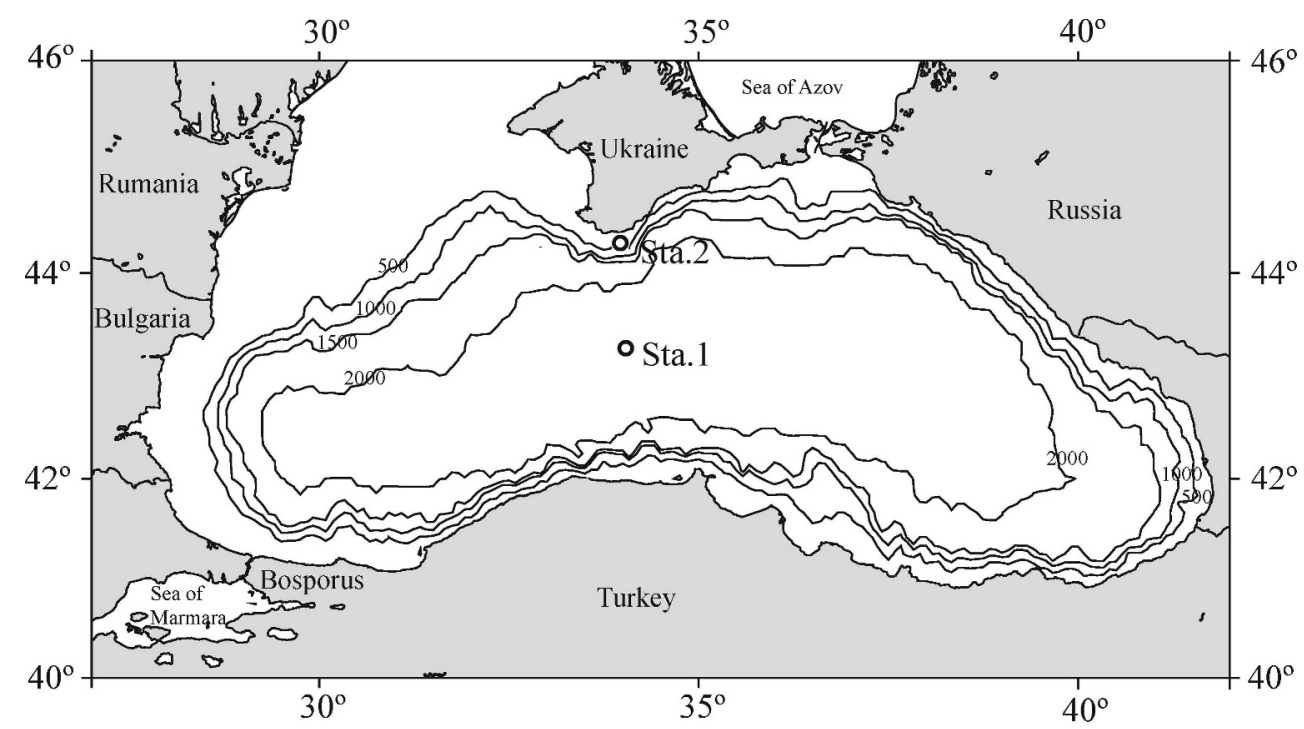

Fig. 1. Map of the Black Sea showing the locations of the two stations sampled.

gen compounds (Sigma-Aldrich) were added (Table 1). The resulting ${ }^{15} \mathrm{~N}$-labeling percentage of nitrogen pools was $>70 \%$ for ${ }^{15} \mathrm{NO}_{3}^{-},>93 \%$ for ${ }^{15} \mathrm{NO}_{2}^{-}$, and $>60 \%$ for ${ }^{15} \mathrm{NH}_{4}^{+}$, as determined from the concentrations before and after additions. Promptly thereafter, the bottles were closed again with butyl rubber stoppers that were perforated with two glass tubes connected to Viton tubing so that the water sample could be purged with helium gas for 15 minutes, which facilitates the detection of $\mathrm{N}_{2}$ production (Dalsgaard et al. 2003). After purging, the water was dispensed into

Table 1. Summary of ${ }^{15} \mathrm{~N}$ incubation experiments. Oxygen concentrations represent mean $\pm \mathrm{SE}$ of measurements made during each incubation.

\begin{tabular}{|c|c|c|c|c|c|}
\hline Experiment & Sampling date & Station & Depth (m) & Tracer additions $\left(\mu \mathrm{mol} \mathrm{L}^{-1}\right)$ & $\begin{array}{l}\text { Treatments with } \mathrm{O}_{2} \text {, } \\
\text { formate, and } \mathrm{H}_{2} \mathrm{~S} \\
\qquad(\mu \mathrm{mol} \mathrm{L}-1)\end{array}$ \\
\hline \multirow[t]{6}{*}{ 1. General } & 18 Aug & Sta. 1 & 85 & $\begin{array}{l}{ }^{15} \mathrm{NH}_{4}^{+}(5),{ }^{15} \mathrm{NO}_{2}^{-}(5),{ }^{15} \mathrm{NO}_{3}^{-}(10) \\
{ }^{15} \mathrm{NO}_{3}^{-}+14 \mathrm{NH}_{4}^{+}(10+5)\end{array}$ & No addition \\
\hline & & & 90 & $*$ & $*$ \\
\hline & & & 95 & $*$ & * \\
\hline & & & 100 & $*$ & * \\
\hline & & & 105 & $*$ & * \\
\hline & & & 110 & $*$ & * \\
\hline \multirow[t]{9}{*}{ 2. Oxygen } & 19 Aug & Sta. 1 & 100 & ${ }^{15} \mathrm{NH}_{4}^{+}+{ }^{14} \mathrm{NO}_{2}^{-}(5+5)$ & $0.07 \pm 0.5$ (control) $\ddagger$ \\
\hline & & & & $\dagger+4$ & $4.10 \pm 0.22$ \\
\hline & & & & $\dagger$ & $8.74 \pm 1.02$ \\
\hline & & & & $\dagger$ & $13.1 \pm 1.32$ \\
\hline & & & & $\dagger$ & $8.77 \pm 0.34+86 \mu \mathrm{mol} \mathrm{L}^{-1} \mathrm{ATU}$ \\
\hline & & & & $15 \mathrm{NO}_{2}^{-}(5)$ & $0.23 \pm 0.08$ (control) $\$$ \\
\hline & & & & $\dagger$ & $3.22 \pm 0.66$ \\
\hline & & & & $\dagger$ & $7.49 \pm 1.34$ \\
\hline & & & & $\dagger$ & $14.2 \pm 1.19$ \\
\hline \multirow[t]{2}{*}{ 3. Formate } & 19 Aug & Sta. 1 & 105 & ${ }^{15} \mathrm{NO}_{3}^{-}+{ }^{14} \mathrm{NH}_{4}^{+}(10+5)$ & No addition (control) \\
\hline & & & & $15 \mathrm{NO}_{3}^{-}+{ }^{-14} \mathrm{NH}_{4}^{+}(10+5)$ & Formate (5) \\
\hline \multirow[t]{4}{*}{ 4. Sulfide } & 20 Aug & Sta. 1 & 115 & ${ }_{15} \mathrm{NH}_{4}^{+}$ & No addition (control) \\
\hline & & & & ${ }^{15} \mathrm{NH}_{4}^{+}$ & $\mathrm{H}_{2} \mathrm{~S}(4)$ \\
\hline & & & & ${ }^{15} \mathrm{NO}_{2}^{-\frac{1}{2}}$ & $\S$ \\
\hline & & & & $15 \mathrm{NO}_{2}^{-}$ & $\S$ \\
\hline
\end{tabular}

* Same treatments as listed for $85 \mathrm{~m}$.

$\uparrow$ Same tracer treatments, different additions of oxygen.

\$ Concentrations of $\mathrm{O}_{2}$, listed as mean and standard error, are calculated for each treatment from the average of up to 10 Exetainer vials (five time points, one to two vials at each time point).

$\S$ The same treatments as listed for ${ }^{15} \mathrm{NH}_{4}^{+}$. 
sets of 12.6-mL glass vials (Exetainer, Labco), keeping a slight helium overpressure and allowing an overflow of more than one volume. The Exetainer vials were filled completely and immediately screw-capped with butyl rubber septa and incubated close to in situ temperature $\left(10 \pm 2^{\circ} \mathrm{C}\right)$. Incubations were stopped by sampling of three vials five to seven times (after approximately 0, 6, 15, 30, 48,75 , and $100 \mathrm{~h}$ ) during each of the incubation series. For isotopic analysis, $2 \mathrm{~mL}$ of water were removed with syringe and needle through the septum while replacing the volume with helium. To stop microbial activity, $100 \mu \mathrm{L}$ of $50 \%$ (w/ v) $\mathrm{ZnCl}_{2}$ or saturated $\mathrm{HgCl}_{2}$ were injected into the Exetainer vials, and the vials were stored upside down until stable isotope analysis. The $2 \mathrm{~mL}$ of water removed were frozen immediately for later nutrient analysis. In the incubation series without addition of $\mathrm{NH}_{4}^{+}$, one of the triplicate Exetainer vials was opened, and $2.6 \mathrm{~mL}$ of water were removed for $\mathrm{NO}_{2}^{-}$measurements, after which OPA reagent (orthophtaldialdehyde) was added to the remaining water sample for $\mathrm{NH}_{4}^{+}$analysis (see below). In the oxygen experiment, two additional vials were sampled for determination of oxygen (see below).

General experiment: Depth distribution of anammox and denitrification activity -To determine the relative role of anammox and denitrification for $\mathrm{N}$ loss from the suboxic zone, the CTD-pump system was used to collect water samples from 85, 90, 95, 100, 105, and $110 \mathrm{~m}$ at Sta. 1. Four different ${ }^{15} \mathrm{~N}$ tracer treatments were used: ${ }^{15} \mathrm{NH}_{4}^{+}(5)$, ${ }^{15} \mathrm{NO}_{2}^{-}(5),{ }^{15} \mathrm{NO}_{3}^{-}(10)$, and ${ }^{15} \mathrm{NO}_{3}^{-}+{ }^{14} \mathrm{NH}_{4}^{+}(10+5)$, with the final added concentrations listed in $\mu \mathrm{mol} \mathrm{L}-1$ in parentheses (Table 1). The same concentrations were used in the subsequent experiments with oxygen, formate, and sulfide.

Oxygen and formate experiments - The oxygen and formate experiments were performed with water sampled from 100 and $105 \mathrm{~m}$, respectively, at Sta. 1 obtained with Go-Flo bottles.

Two treatments, ${ }^{15} \mathrm{NO}_{2}^{-}$and ${ }^{15} \mathrm{NH}_{4}^{+}+{ }^{14} \mathrm{NO}_{2}^{-}$, were used in the oxygen experiment (Table 1). In the ${ }^{15} \mathrm{NH}_{4}^{+}$ incubations, ${ }^{14} \mathrm{NO}_{2}^{-}$was added to trap any ${ }^{15} \mathrm{NO}_{2}^{-}$formed during nitrification. The analysis of nitrification is described in a separate paper (Lam et al. 2007). After purging with helium, filling, and sealing the Exetainer vials, three sets of vials were injected with 125,250 , and $500 \mu \mathrm{L}$ of airsaturated seawater from the incubation depth, respectively, with excess water expelled through a 1-mL syringe without piston. A fourth set of vials were not injected, serving as the control. Concentrations of $\mathrm{O}_{2}$ were monitored during the incubation. Thus, simultaneously with the sampling for stable isotope and nutrient measurements (after $\sim 0,12,24$, $36,48 \mathrm{~h}$ of incubation), one or two Exetainer vials per treatment were carefully opened, and an oxygen microsensor (ox-100, Unisense) was inserted immediately into the vial to determine the oxygen concentration. The resulting concentrations of $\mathrm{O}_{2}$ are listed in Table 1 as averages for the duration of the experiment, and we will refer to the treatments as control $\left(\mathrm{O}_{2}\right.$ below detection of $\sim 0.5 \mu \mathrm{mol}$ $\left.\mathrm{L}^{-1}\right)$, low $(\sim 3.5 \mu \mathrm{mol} \mathrm{L}-1)$, intermediate $(\sim 8 \mu \mathrm{mol} \mathrm{L}-1)$, and high $\left(\sim 13.5 \mu \mathrm{mol} \mathrm{L}^{-1}\right)$, respectively. Two parallel incubations were performed with ${ }^{15} \mathrm{NH}_{4}^{+}+{ }^{14} \mathrm{NO}_{2}^{-}$and the intermediate oxygen treatment $\left(\sim 8.7 \mu \mathrm{mol} \mathrm{L}^{-1}\right)$. One of these treatments received allylthiourea (ATU) to a final concentration of $86 \mu \mathrm{mol} \mathrm{L}^{-1}$ together with the ${ }^{15} \mathrm{~N}$ tracer. ATU is a specific inhibitor of ammonium oxidation by nitrifying bacteria (Hall 1984; Hall and Jeffries 1984; Bédard and Knowles 1989), while ATU has no effect on anammox activity in marine sediments or cultured anammox bacteria (Dapena-Mora et al. 2007; Jensen et al. 2007).

For the experiment with formate, two parallel incubations with additions of ${ }^{15} \mathrm{NO}_{3}^{-}+{ }^{14} \mathrm{NH}_{4}^{+}$were performed, one of which served as a control while the other received sodium formate to a final concentration of $5 \mu \mathrm{mol} \mathrm{L}-1$ (Table 1).

Sulfide experiment-The sulfide experiment was performed at Sta. 2, where samples were taken from the chemocline at $115 \mathrm{~m}$ depth in a Go-Flo bottle. Four glass bottles were purged with helium after the addition of tracers $\left({ }^{15} \mathrm{NH}_{4}^{+}\right.$and ${ }^{15} \mathrm{NO}_{2}^{-}$), as described above (Table 1). Each ${ }^{15} \mathrm{~N}$ tracer was added to two glass bottles, of which one acted as a control, receiving no $\mathrm{Na}_{2} \mathrm{~S}$, and the remaining bottles received $\mathrm{Na}_{2} \mathrm{~S}$. Immediately after the purging, $\mathrm{Na}_{2} \mathrm{~S}$ was added to final concentration of $4 \mu \mathrm{mol}$ $\mathrm{L}^{-1}$ with a gastight glass syringe and needle through the stopper. After gentle mixing, the water was transferred into Exetainer vials, and sampling of triplicates for stable isotope and nutrient measurements was performed at $\sim 0$, $6,12,30$, and $42 \mathrm{~h}$, as described above. After the stable Nisotopic composition of $\mathrm{N}_{2}$ had been determined (see below), the remaining water in the Exetainer vials was analyzed for sulfide.

Analysis and calculations-Both $\mathrm{NH}_{4}^{+}$and $\mathrm{NO}_{2}^{-}$were analyzed immediately after sampling. Ammonium was analyzed fluorometrically using the OPA (orthophtaldialdehyde) method (Holmes et al. 1999), and $\mathrm{NO}_{2}^{-}$was analyzed spectrophotometrically (Grasshoff 1983). Samples for nutrients were stored frozen, and later $\mathrm{NO}_{3}^{-}, \mathrm{NO}_{2}^{-}$, $\mathrm{NH}_{4}^{+}$, and $\mathrm{PO}_{4}^{3-}$ (detection limits: 0.1, 0.03, 0.3, and $0.1 \mu \mathrm{mol} \mathrm{L}-1$, respectively) were measured with an autoanalyzer (TRAACS 800, Bran and Lubbe). Sulfide was measured spectrophotometrically by the methylene blue technique (detection limit: $1 \mu \mathrm{mol} \mathrm{L}-1$ ) (Cline 1969). At Sta. 2, $\mathrm{NO}_{x}^{-}$was measured at the sampling depth $(115 \mathrm{~m})$ by chemiluminescence detection of NO after vanadium chloride reduction (detection limit: 0.5 and $0.1-0.2 \mu \mathrm{mol}$ $\mathrm{L}^{-1}$ for $\mathrm{NO}_{3}^{-}$and $\mathrm{NO}_{2}^{-}$, respectively) (Braman and Hendrix 1989).

The isotopic composition and concentration of $\mathrm{N}_{2}$ was determined using a gas chromatograph-isotope ratio mass spectrometer (Fisons VG Optima) with a continuous flow inlet by injecting $1-\mathrm{mL}$ samples of headspace directly from the Exetainer vials. Production of $\mathrm{N}_{2}$ through denitrification and anammox was calculated from the excess concentrations of ${ }^{15} \mathrm{~N}$-labeled $\mathrm{N}_{2}$ (i.e., ${ }^{14} \mathrm{~N}^{15} \mathrm{~N}$ and ${ }^{15} \mathrm{~N}^{15} \mathrm{~N}$ ) and the ${ }^{15} \mathrm{~N}$-labeling of the $\mathrm{NO}_{2}^{-}, \mathrm{NO}_{3}^{-}$, or $\mathrm{NH}_{4}^{+}$pools $\left(\mathrm{F}_{\mathrm{x}}\right)$, according to Thamdrup and Dalsgaard 
(2000, 2002). Thus, for incubations with ${ }^{15} \mathrm{NO}_{2}^{-}$(and similarly with ${ }^{15} \mathrm{NO}_{3}^{-}$),

$$
\begin{gathered}
D={ }^{15} N^{15} N \times F_{\text {nitrite }}^{-2} \\
A={ }^{14} N^{15} N \times F_{\text {nitrite }}^{-1}-\left[D \times 2 \times\left(1-F_{\text {nitrite }}\right)\right]
\end{gathered}
$$

where $D$ and $A$ denotes production of $\mathrm{N}_{2}$ through denitrification and anammox, respectively, and $F_{x}$ is the mole fraction of ${ }^{15} \mathrm{~N}$ label in $\mathrm{NO}_{2}^{-}$or $\mathrm{NO}_{3}^{-}$.

For incubations with ${ }^{15} \mathrm{NH}_{4}^{+}$,

$$
A={ }^{14} N^{15} N \times F_{\text {ammonium }}^{-1}
$$

This calculation assumes that anammox is the sole source of ${ }^{14} \mathrm{~N}^{15} \mathrm{~N}$ and that anammox produces only ${ }^{14} \mathrm{~N}^{14} \mathrm{~N}$ and ${ }^{14} \mathrm{~N}^{15} \mathrm{~N}$ with random pairing of one molecule from each of the $\mathrm{NO}_{2}^{-}$and $\mathrm{NH}_{4}^{+}$pools (van de Graaf et al. 1995; Thamdrup and Dalsgaard 2002).

In a few incubations with ${ }^{15} \mathrm{NH}_{4}^{+}$, we observed a production of ${ }^{15} \mathrm{~N}^{15} \mathrm{~N}$. As discussed below and detailed by Lam and coworkers (2007), the ${ }^{15} \mathrm{~N}^{15} \mathrm{~N}$ production could be explained by a coupling of ammonium oxidation of ${ }^{15} \mathrm{NH}_{4}^{+}$to ${ }^{15} \mathrm{NO}_{2}^{-}$through nitrification, followed by a oneto-one pairing of $15 \mathrm{NO}_{2}^{-}$and ${ }^{15} \mathrm{NH}_{4}^{+}$by anammox. In this case, Eq. 3 does not suffice to calculate anammox rates since ${ }^{14} \mathrm{~N}^{15} \mathrm{~N}$ may be produced by pairing of either added ${ }^{15} \mathrm{NH}_{4}^{+}$and native ${ }^{14} \mathrm{NO}_{2}^{-}$or native ${ }^{14} \mathrm{NH}_{4}^{+}$and ${ }^{15} \mathrm{NO}_{2}^{-}$ generated through nitrification. If denitrification is not active, it is possible to derive total anammox rates from ${ }^{15} \mathrm{NH}_{4}^{+}$incubations through the accumulation of both ${ }^{14} \mathrm{~N}^{15} \mathrm{~N}$ and ${ }^{15} \mathrm{~N}^{15} \mathrm{~N}$. Thus, the relationship between the production of labeled $\mathrm{N}_{2}$ and anammox follows Eq. 4 and 5:

$$
\begin{gathered}
{ }^{14} N^{15} N=A \times\left[F_{\text {ammonium }} \times\left(1-F_{\text {nitrite }}\right)+\right. \\
\left.\left(1-F_{\text {ammonium }}\right) \times F_{\text {nitrite }}\right] \\
{ }^{15} N^{15} N=A \times F_{\text {ammonium }} \times F_{\text {nitrite }}
\end{gathered}
$$

It follows from Eq. 5 that

$$
F_{\text {nitrite }}=\frac{{ }^{15} N^{15} \mathrm{~N}}{A \times F_{\text {ammonium }}}
$$

And, by substituting $F_{\text {nitrite }}$ in Eq. 4 with Eq. 6 and rearranging, we obtain

$A=\left[{ }^{14} N^{15} N+2 \times{ }^{15} N^{15} N-\left(\frac{{ }^{15} N^{15} N}{F_{\text {ammonium }}}\right)\right] \times F_{\text {ammonium }}^{-1}$

Note that Eq. 7 reduces to Eq. 3 when ${ }^{15} \mathrm{~N}^{15} \mathrm{~N}=0$ and that $\mathrm{A} \approx{ }^{14} \mathrm{~N}^{15} \mathrm{~N}+{ }^{15} \mathrm{~N}^{15} \mathrm{~N}$ when $\mathrm{F}_{\text {ammonium }} \approx 1$.

Rates were calculated from linear regression of ${ }^{15} \mathrm{~N}$ labeled $\mathrm{N}_{2}$ concentrations as a function of time. Production of ${ }^{15} \mathrm{~N}$-labeled $\mathrm{N}_{2}$ was deemed significant when slopes were significantly greater than zero as evaluated by a one-tailed $t$-test at the 5\% level. Similarly, a two-tailed $t$-test at the 5\% level was used for comparing slopes. The ${ }^{15} \mathrm{~N}$-labeling of $\mathrm{NO}_{2}^{-}, \mathrm{NO}_{3}^{-}$, and $\mathrm{NH}_{4}^{+}\left(F_{x}\right)$ was calculated from their concentrations before and after addition of tracer. The $\mathrm{N}$ isotope composition of $\mathrm{NH}_{4}^{+}$was analyzed in selected samples after conversion to $\mathrm{N}_{2}$ with hypobromite (Risgaard-Petersen et al. 1995).

\section{Results}

Hydrochemistry at Sta. 1 in the central Black SeaVertical profiles of temperature, salinity, density, and oxygen at Sta. 1 in the central part of the basin are shown in Figure 2. The pycnocline was centered at 16-17-m depth, where the density was influenced largely by temperature, which is characteristic for the summer period (Özsoy and Ünlüata 1997; Sorokin 2002). The halocline and oxycline coincided over a depth interval of approximately 20-95 m (Fig. 2A,B). Dissolved oxygen concentrations less than $10 \mu \mathrm{mol} \mathrm{L}^{-1}$ occurred below $81 \mathrm{~m}$ (at $\sigma_{\mathrm{t}}=15.74 \mathrm{~kg} \mathrm{~m}^{-3}$, for comparison with studies in other parts of the Black Sea), and oxygen went below the detection limit of $1-$ $2 \mu \mathrm{mol} \mathrm{L}^{-1}$ at $97 \mathrm{~m}\left(\sigma_{\mathrm{t}}=16.02 \mathrm{~kg} \mathrm{~m}^{-3}\right)$. The suboxic zone extended to $\sim 112 \mathrm{~m}\left(\sigma_{\mathrm{t}}=16.20 \mathrm{~kg} \mathrm{~m}^{-3}\right)$, where hydrogen sulfide started to accumulate, increasing to $5.2 \mu \mathrm{mol} \mathrm{L}-1$ at $123 \mathrm{~m}$ (Fig. 2B). Between 85 and $110 \mathrm{~m}$, the depth interval sampled for tracer incubations, oxygen concentrations ranged from below detection to $7.4 \mu \mathrm{mol} \mathrm{L}-1$. A peak of nitrate was located at the bottom of the oxic zone, with nitrate concentrations of $\sim 5 \mu \mathrm{mol} \mathrm{L}^{-1}$ centered at $76 \mathrm{~m}\left(\sigma_{\mathrm{t}}\right.$ $=15.60 \mathrm{~kg} \mathrm{~m}^{-3}$; Fig. 2C). Below this depth, nitrate decreased continuously to below detection at $100 \mathrm{~m}\left(\sigma_{\mathrm{t}}=\right.$ $\left.16.05 \mathrm{~kg} \mathrm{~m}^{-3}\right)$. Concentrations of ammonium were typically below $90 \mathrm{nmol} \mathrm{L}^{-1}$ in the oxic and upper suboxic zone (shallower than $99 \mathrm{~m} ; \sigma_{\mathrm{t}}=16.04 \mathrm{~kg} \mathrm{~m}^{-3}$; Fig. 2C). Ammonium started to accumulate just below the depth of nitrate disappearance, where concentrations increased from $0.4 \mu \mathrm{mol} \mathrm{L}-1$ at $99 \mathrm{~m}$ to $7.5 \mu \mathrm{mol} \mathrm{L}^{-1}$ at $123 \mathrm{~m}$. Nitrite concentrations were slightly elevated $\left(20-42 \mathrm{nmol} \mathrm{L}^{-1}\right)$ at approximately 55,80 , and $105 \mathrm{~m}$ and were otherwise close to the detection limit at all other depths sampled.

Depth distributions of anammox and denitrification in the central Black Sea-Anaerobic ammonium oxidation to $\mathrm{N}_{2}$ was detected in both ${ }^{15} \mathrm{NH}_{4}^{+}$and ${ }^{15} \mathrm{NO}_{2}^{-}$incubations in the suboxic zone of the central Black Sea (Sta. 1; all rates listed in Table 2). In five out of six anoxic incubations with ${ }^{15} \mathrm{NH}_{4}^{+}$only (all depths except $100 \mathrm{~m}$ ), all the ${ }^{15} \mathrm{~N}$ converted to $\mathrm{N}_{2}$ was recovered as ${ }^{14} \mathrm{~N} 15 \mathrm{~N}$, while concentrations of ${ }^{15} \mathrm{~N}$-labeled $\mathrm{N}_{2}$ with mass $30\left(15 \mathrm{~N}^{15} \mathrm{~N}\right)$ were unaffected (an example with ${ }^{15} \mathrm{NH}_{4}^{+}+{ }^{14} \mathrm{NO}_{2}^{-}$from the oxygen experiment is shown in Fig. 3A). As in previous experiments (Dalsgaard and Thamdrup 2002; Thamdrup and Dalsgaard 2002; Thamdrup et al. 2006; van de Graaf et al. 1995), the exclusive production of ${ }^{14} \mathrm{~N}^{15} \mathrm{~N}$ without delay indicated anammox as the active process, which combines $\mathrm{NH}_{4}^{+}$with $\mathrm{NO}_{2}^{-}$in a $1: 1$ stoichiometry, and excluded a significant contribution from the alternative pathways of anaerobic oxidation of $\mathrm{NH}_{4}^{+}$to $\mathrm{NO}_{x}^{-}$or $\mathrm{N}_{2}$ with manganese oxide (Luther et al. 1997; Hulth et al. 1999). In the sixth incubation with ${ }^{15} \mathrm{NH}_{4}^{+}$, from $100-\mathrm{m}$ depth, significant production of both ${ }^{14} \mathrm{~N}^{15} \mathrm{~N}$ and ${ }^{15} \mathrm{~N}^{15} \mathrm{~N}$ was observed with no lag phase at rates of $5.4 \pm 1.0$ and $4.6 \pm$ $0.7 \mathrm{nmol} \mathrm{L}^{-1} \mathrm{~d}^{-1}$, respectively (Table 2 ). 


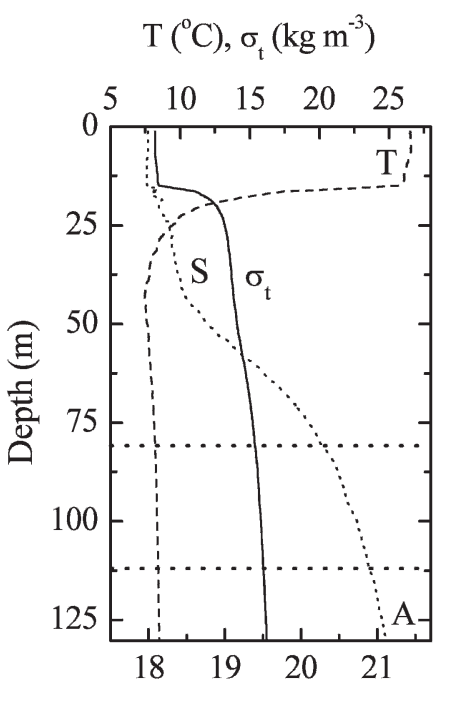

$\mathrm{S}$
$\mathrm{O}_{2}\left(\mu \mathrm{mol} \mathrm{L}{ }^{-1}\right)$
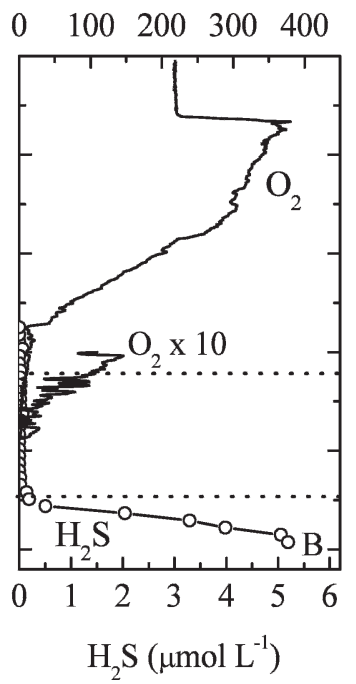

$\mathrm{NH}_{4}^{+}, \mathrm{NO}_{2}^{-}, \mathrm{NO}_{3}^{-}\left(\mu \mathrm{mol} \mathrm{L}{ }^{-1}\right)$ Anammox rate $\left(\mathrm{nmol} \mathrm{L}^{-1} \mathrm{~N}_{2} \mathrm{~d}^{-1}\right)$
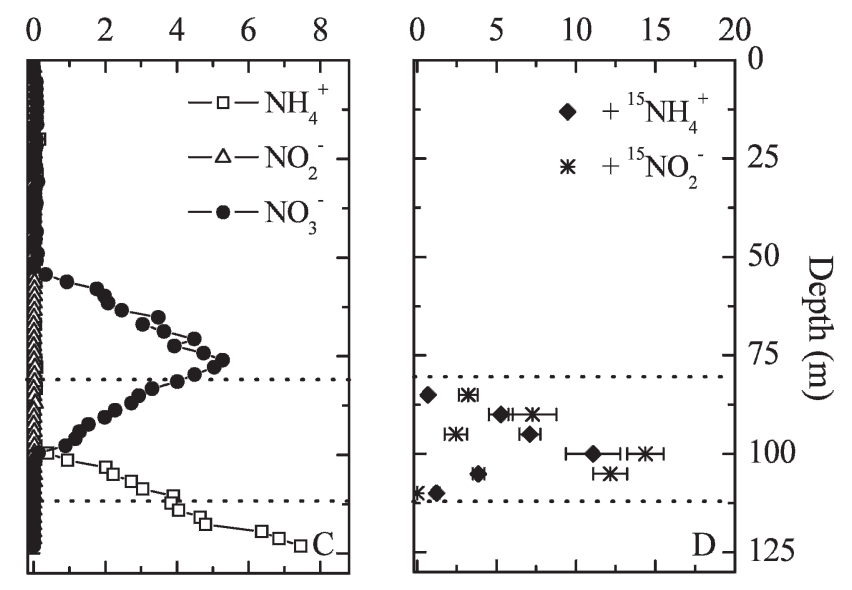

Fig. 2. Physical and chemical zonation of the water column measured at Sta. 1 in the central part of the Black Sea (A-C) and distribution of anammox throughout the suboxic zone (D). (A) Temperature, salinity and sigma-T. (B) Concentrations of oxygen and sulfide. (C) Concentrations of fixed inorganic nitrogen compounds. (D) Rates $\pm \mathrm{SE}$ of anammox based on ${ }^{15} \mathrm{NH}_{4}^{+}$and ${ }^{15} \mathrm{NO}_{2}^{-}$ incubations. The dotted horizontal lines mark the upper and lower boundaries of the suboxic zone defined by oxygen concentrations below $10 \mu \mathrm{mol} \mathrm{L}-1$ and no measurable sulfide.

In general agreement with the results based on ${ }^{15} \mathrm{NH}_{4}^{+}$, an accumulation of ${ }^{14} \mathrm{~N}^{15} \mathrm{~N}$ was also observed in five out of six of the ${ }^{15} \mathrm{NO}_{2}^{-}$incubations (all depths except $110 \mathrm{~m}$ ), starting immediately after addition of tracer to the anoxic incubations (Table 2). Although the $\mathrm{NO}_{2}^{-}$pool was almost fully labeled $\left(F_{\text {nitrite }}>0.92\right)$, there was no significant production of ${ }^{15} \mathrm{~N}^{15} \mathrm{~N}$ in any of the incubations (Table 2). Production of ${ }^{15} \mathrm{~N}$-labeled $\mathrm{N}_{2} \mathrm{O}$ was also not detected at either of the two depths selected for $\mathrm{N}_{2} \mathrm{O}$ analysis (100 and $105 \mathrm{~m}$; detection limit: $0.5 \mathrm{nmol} \mathrm{L}-1 \mathrm{~d}^{-1}$; data not shown). Thus, the initial production of ${ }^{14} \mathrm{~N}^{15} \mathrm{~N}$ in our incubations with ${ }^{15} \mathrm{NO}_{2}^{-}$could be attributed to anammox, consistent with the ${ }^{15} \mathrm{NH}_{4}^{+}$incubations, whereas denitrification was not detected at Sta. 1.

Anammox rates derived from the ${ }^{15} \mathrm{NH}_{4}^{+}$and ${ }^{15} \mathrm{NO}_{2}^{-}$ experiments at the central station are shown in Fig. 2D and Table 2. The rates were calculated by Eq. 2 and 3, except for the result with ${ }^{15} \mathrm{NH}_{4}^{+}$at $100 \mathrm{~m}$, where a significant production of both ${ }^{15} \mathrm{~N}^{14} \mathrm{~N}$ and ${ }^{15} \mathrm{~N}^{15} \mathrm{~N}$ was observed. This is the first time that a ${ }^{15} \mathrm{~N}^{15} \mathrm{~N}$ production from ${ }^{15} \mathrm{NH}_{4}^{+}$has been observed in this type of incubation. The ${ }^{15} \mathrm{~N}^{15} \mathrm{~N}$ production was best explained by a coupling of anammox to ammonium oxidation to nitrite by nitrifiers, as shown in a parallel study of nitrification in the suboxic zone (Lam et al. 2007; see discussion below). Thus, ${ }^{15} \mathrm{~N}^{15} \mathrm{~N}$ resulted from the oxidation of ${ }^{15} \mathrm{NH}_{4}^{+}$to ${ }^{15} \mathrm{NO}_{2}^{-}$, followed by a one-to-one combination of ${ }^{15} \mathrm{NO}_{2}^{-}$ and ${ }^{2} \mathrm{NH}_{4}^{+}$through anammox. Accordingly, Eq. 7 was usable for the calculation of the anammox rate in these two cases because denitrification was not detected. Anammox rates showed similar depth distributions with the two types of incubations, varying between 1.0 and $11.1 \mathrm{nmol} \mathrm{N} \mathrm{L}^{-1} \mathrm{~d}^{-1}$ in the incubations with ${ }^{15} \mathrm{NH}_{4}^{+}$ and from below detection to $14.7 \mathrm{nmol} \mathrm{N} \mathrm{L}^{-1} \mathrm{~d}^{-1}$ in the
${ }^{15} \mathrm{NO}_{2}^{-}$incubations. The activity increased with depth through the upper part of the suboxic zone, peaked at $100 \mathrm{~m}$ depth, and decreased below toward the sulfidic zone. The low rates observed did not result in detectable changes in the bulk concentrations of $\mathrm{NH}_{4}^{+}$and $\mathrm{NO}_{2}^{-}$ (data not shown). The depth-integrated anammox rates were $293 \pm 51$ and $406 \pm 73 \mu \mathrm{mol} \mathrm{N} \mathrm{m}^{-2} \mathrm{~d}^{-1}$ with ${ }^{15} \mathrm{NH}_{4}^{+}$and ${ }^{15} \mathrm{NO}_{2}^{-}$, respectively, with no significant difference between these two estimated figures $(p>0.05)$.

Incubations with ${ }^{15} \mathrm{NO}_{3}^{-}$resulted in a relatively small production of ${ }^{14} \mathrm{~N}^{15} \mathrm{~N}$ but not ${ }^{15} \mathrm{~N}^{15} \mathrm{~N}$, with rates ranging from below detection to $3.1 \pm 1.2 \mathrm{nmol} \mathrm{L}^{-1} \mathrm{~d}^{-1}$ (Table 2; an example from the formate experiment is shown in Fig. 3C,D). In general, nitrate reduction to $\mathrm{N}_{2}$ was not stimulated by the addition of $\mathrm{NH}_{4}^{+}$, and there was no clear depth trend in the distribution of the rates. The lack of ${ }^{15} \mathrm{~N}^{15} \mathrm{~N}$ production is consistent with the absence of denitrification in the ${ }^{15} \mathrm{NO}_{2}^{-}$incubations and shows that denitrifiers did not somehow shunt nitrogen around the nitrite pool. Nitrate reduction is expected to produce nitrite as a free intermediate, and the results therefore demonstrate that nitrate reduction is a source of nitrite. As discussed by Thamdrup and coworkers (2006), however, accurate calculation of anammox rates from incubations with ${ }^{15} \mathrm{NO}_{3}^{-}$would require knowledge of the mixing of generated ${ }^{15} \mathrm{NO}_{2}^{-}$with the ambient nitrite pool. In the absence of this information, we cannot further compare rates from ${ }^{15} \mathrm{NO}_{3}^{-}$and ${ }^{15} \mathrm{NO}_{2}^{-}$incubations.

Effect of oxygen-A significant production of ${ }^{14} \mathrm{~N}^{15} \mathrm{~N}$ was observed with no lag phase in all treatments with ${ }^{15} \mathrm{NH}_{4}^{+}$plus unlabeled $\mathrm{NO}_{2}^{-}$as well as in those with ${ }_{15} \mathrm{NO}_{2}^{-}$, except for those with the highest concentration of added oxygen (example in Fig. 3A,B). There was no 


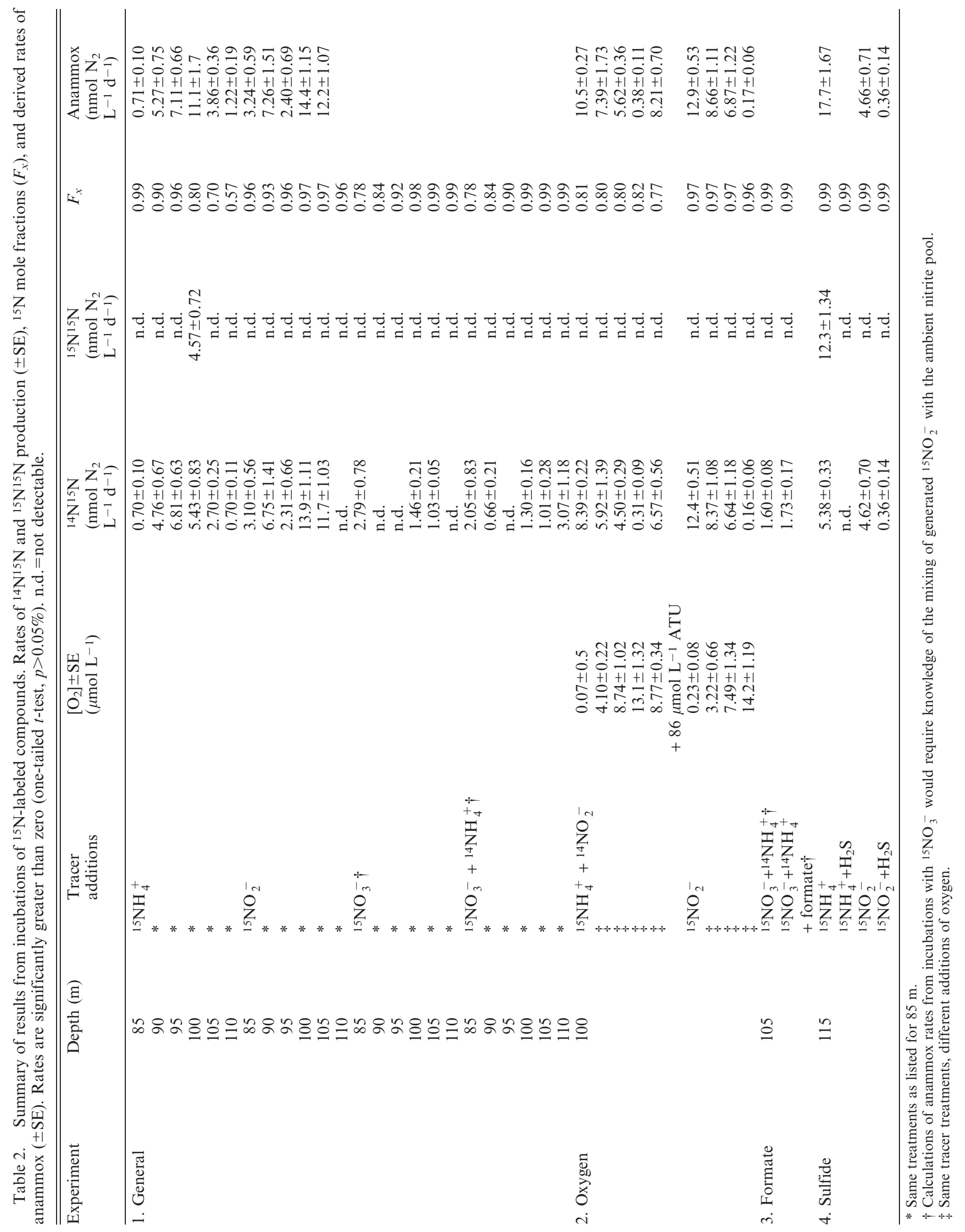



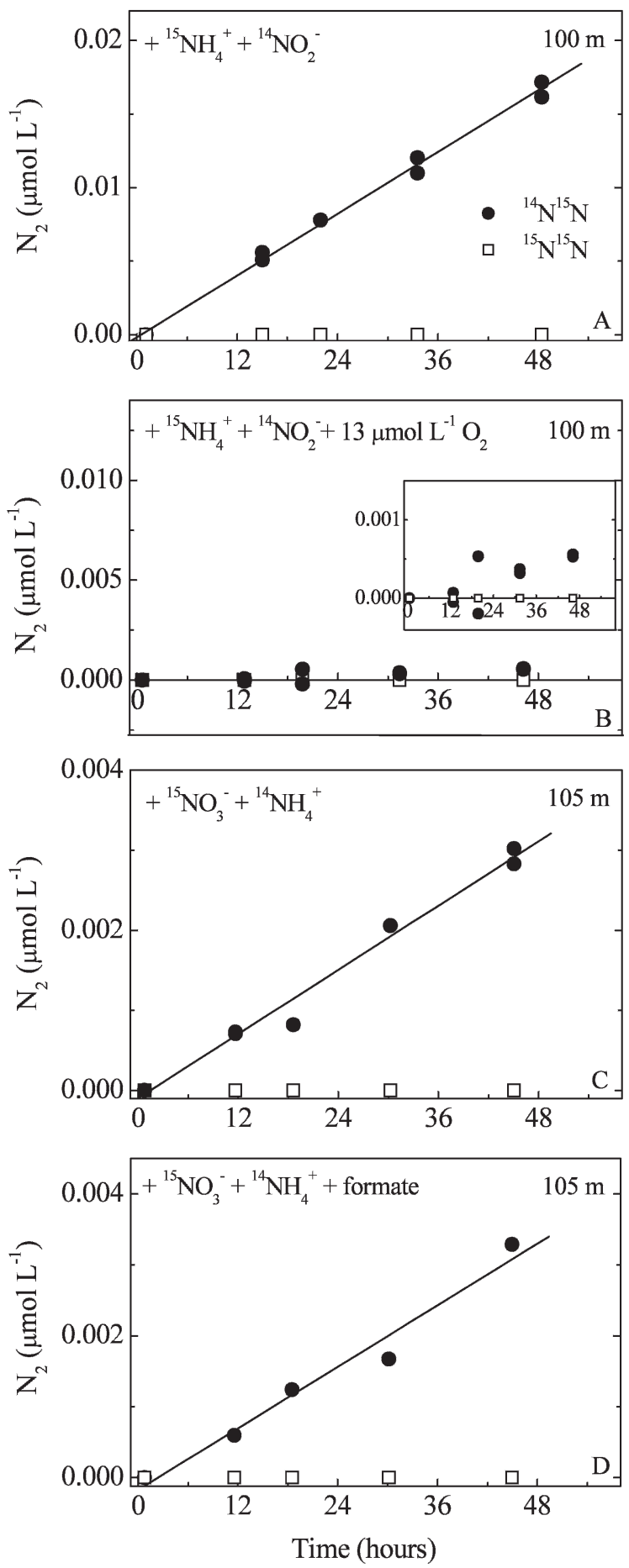

Fig. 3. Examples of the production of $15 \mathrm{~N}$-labeled $\mathrm{N}_{2}$ during incubations. Data from Sta. 1, 19 August. (A) Control incubation with ${ }^{15} \mathrm{NH}_{4}^{+}+{ }^{14} \mathrm{NO}_{2}^{-}$. (B) Incubation with ${ }^{15} \mathrm{NH}_{4}^{+}+{ }^{14} \mathrm{NO}_{2}^{-}$ and high oxygen concentration $\left(13.1 \pm 1.32 \mu \mathrm{mol} \mathrm{L}{ }^{-1}\right)$. (C) Control incubation with ${ }^{15} \mathrm{NO}_{3}^{-}+{ }^{14} \mathrm{NH}_{4}^{+}$. (D) Incubation with ${ }^{15} \mathrm{NO}_{3}^{-}+{ }^{14} \mathrm{NH}_{4}^{+}$and $5 \mu \mathrm{mol} \mathrm{L}-1$ of formate. Rates of anammox were estimated from linear regressions and Eq. 1-3 and 7. accumulation of ${ }^{15} \mathrm{~N}^{15} \mathrm{~N}$ in any of the incubations, indicating that anammox was the only detectable process. Anammox rates in the control incubations without oxygen addition were statistically similar to those obtained in the same type of incubations at the same depth $(100 \mathrm{~m})$ on the day before (Table 2).

Oxygen concentrations remained at $4.1 \pm 0.2$ and $8.7 \pm$ $1.0 \mu \mathrm{mol} \mathrm{L} \mathrm{L}^{-1}$ in the two $15 \mathrm{NH}_{4}^{+}+14 \mathrm{NO}_{2}^{-}$incubation series that received low and intermediate levels of oxygen, respectively. The same was true in the ${ }^{15} \mathrm{NO}_{2}^{-}$incubations, where oxygen concentrations were $3.2 \pm 0.7$ and $7.5 \pm$ $1.3 \mu \mathrm{mol} \mathrm{L}-1$ in the treatments with low and intermediate oxygen additions, respectively. In the series with the largest addition of oxygen, the oxygen concentrations seemed to drop slightly through the incubation (data not shown). Regression-derived rates of oxygen consumption were $-0.11 \pm 0.08$ and $-0.13 \pm 0.05 \mu \mathrm{mol} \mathrm{L}^{-1} \mathrm{~h}^{-1}$ in the ${ }^{15} \mathrm{NH}_{4}^{+}+{ }^{14} \mathrm{NO}_{2}^{-}$and ${ }^{15} \mathrm{NO}_{2}^{-}$incubations, respectively, and only the rate from the ${ }^{15} \mathrm{NO}_{2}^{-}$incubation was statistically significant different from zero $(p<0.05$, as determined by one-tailed $t$-test).

There was a clear negative correlation between anammox activity and oxygen concentration, with a close agreement in the oxygen response of the ${ }^{15} \mathrm{NH}_{4}^{+}+{ }^{14} \mathrm{NO}_{2}^{-}$ and ${ }^{15} \mathrm{NO}_{2}^{-}$incubations (Fig. 4). Compared to the anoxic controls, anammox rates were reduced by $\sim 31 \%, 47 \%$, and $\sim 98 \%$ at low, intermediate, and high oxygen concentrations, respectively $\left(\sim 3.5, \sim 8\right.$, and $\sim 13.5 \mu \mathrm{mol} \mathrm{L}^{-1}$, respectively; Fig. 4). In the incubations with the highest added oxygen concentration, ${ }^{14} \mathrm{~N}^{15} \mathrm{~N}$ production was first detected after $\sim 30 \mathrm{~h}$ of incubation in both treatments $\left(15 \mathrm{NO}_{2}^{-}\right.$and $\left.15 \mathrm{NH}_{4}^{+}+14 \mathrm{NO}_{2}^{-}\right)$, while the production showed no lag in the other treatments (control, low, and intermediate oxygen; Fig. 3A,B). With the addition of ATU, the anammox rate in the incubation with $15 \mathrm{NH}_{4}^{+}+$ ${ }^{14} \mathrm{NO}_{2}^{-}$and intermediate oxygen concentration $(8.77 \pm$ $0.34 \mu \mathrm{mol} \mathrm{L}{ }^{-1}$ ) was somewhat higher than in the parallel incubation without ATU (Fig. 4). The anammox rate in the incubation with ATU at intermediate oxygen concentration corresponded to $78 \%$ of the control level, where no oxygen was added (Fig. 4).

Effect of formate-Addition of $5 \mu \mathrm{mol} \mathrm{L} \mathrm{L}^{-1}$ of formate had no measurable effect on the production of ${ }^{14} \mathrm{~N}^{15} \mathrm{~N}$ by anammox in ${ }^{15} \mathrm{NO}_{3}^{-}+{ }^{14} \mathrm{NH}_{4}^{+}$incubations from $105 \mathrm{~m}$, in which ${ }^{14} \mathrm{~N}^{15} \mathrm{~N}$ production rates of $1.7 \pm 0.2$ and $1.8 \pm 0.1$ nmol $\mathrm{N}_{2} \mathrm{~L}^{-1} \mathrm{~d}^{-1}$ were obtained with and without formate, respectively (Fig. 3C,D; Table 2). No label was recovered as ${ }^{15} \mathrm{~N}^{15} \mathrm{~N}$, and there was no detectable change in the concentration of ${ }^{15} \mathrm{NH}_{4}^{+}$during incubation (detection limit: 2 nmol $\mathrm{L}^{-1}$; data not shown).

Effect of sulfide-Hydrogen sulfide was below detection in situ at $115 \mathrm{~m}$ at Sta. 2. The ambient ammonium

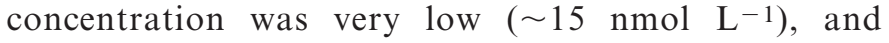
concentrations of nitrate and nitrite were nondetectable.

In the control incubation with ${ }^{15} \mathrm{NH}_{4}^{+}$and undetectable hydrogen sulfide, the production rates of ${ }^{14} \mathrm{~N}^{15} \mathrm{~N}$ and

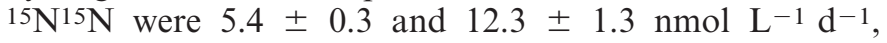
respectively (Table 2). Again Eq. 7 was applied to calculate 


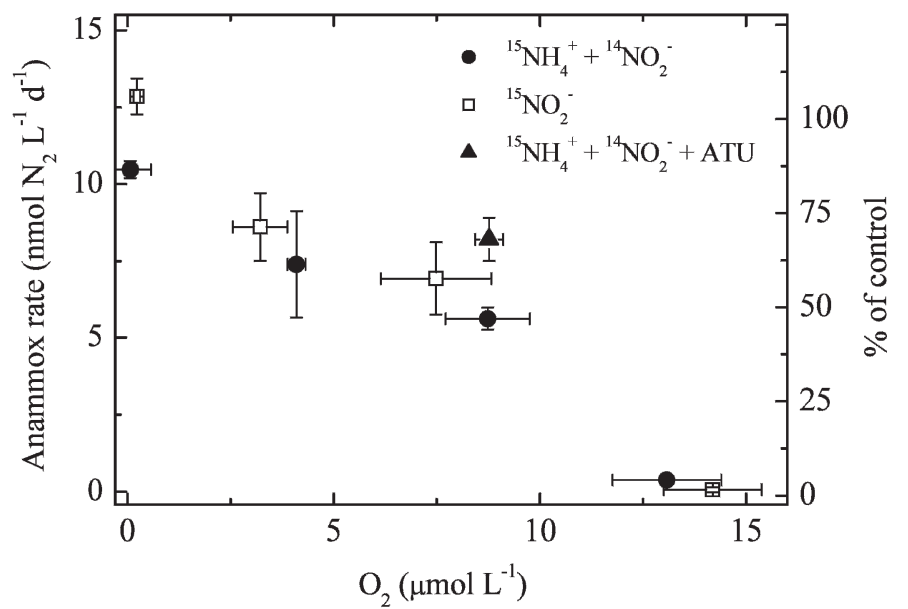

Fig. 4. Anammox rates as a function of oxygen concentrations. Error bars indicate standard errors of rates and oxygen concentrations. Concentrations of oxygen are averages of measurements made during the incubation period. Percentages of control were estimated from average values of anammox rates obtained in ${ }^{15} \mathrm{NH}_{4}^{+}$and ${ }^{15} \mathrm{NO}_{2}^{-}$incubations. The labeling percentages were more or less identical in the incubations.

the rate of anammox due to the production of ${ }^{15} \mathrm{~N}^{15} \mathrm{~N}$ from ${ }^{15} \mathrm{NH}_{4}^{+}$, which was feasible because denitrification was not detected. The production of ${ }^{14} \mathrm{~N}^{15} \mathrm{~N}$ and ${ }^{15} \mathrm{~N}^{15} \mathrm{~N}$ corresponded to an anammox rate of $17.7 \pm 1.7 \mathrm{nmol} \mathrm{\textrm {N } _ { 2 }}$ $\mathrm{L}^{-1} \mathrm{~d}^{-1}$ (Fig. 5).

Addition of sulfide completely inhibited the production of ${ }^{15} \mathrm{~N}$-labeled $\mathrm{N}_{2}$ from ${ }^{15} \mathrm{NH}_{4}^{+}$and inhibited the production of ${ }^{14} \mathrm{~N}^{15} \mathrm{~N}$ in the ${ }^{15} \mathrm{NO}_{2}^{-}$treatment by $92 \%$, compared to the control incubation (Fig. 5). The concentration of $\mathrm{H}_{2} \mathrm{~S}$ ranged between 1.5 and $2.5 \mu \mathrm{mol} \mathrm{\textrm {L } ^ { - 1 }}$ initially in the incubations with added $\mathrm{H}_{2} \mathrm{~S}$ (data not shown).

\section{Discussion}

Depth distribution of anammox activity-The vertical redox zonation and the coinciding disappearance of nitrate and ammonium at $100-\mathrm{m}$ depth at Sta. 1 in the central basin resembled observations previously reported (Fig. 2) (Codispoti et al. 1991; Tebo 1991; Kuypers et al. 2003). The one major difference is that the typical nitrite maximum of $0.08-0.35 \mu \mathrm{mol} \mathrm{L}^{-1}$ near the interface between nitrate and ammonium was missing during our visit.

Our study presents the first experimental quantification of anammox rates through the suboxic zone of the central Black Sea, supporting the previous study by Kuypers and coworkers (2003) that showed anammox bacteria to be present and active. The depth distribution of anammox rates corresponded with the distribution of anammox bacteria as determined by FISH and quantitative PCR during the same cruise (Fig. 2D) (Lam et al. 2007). The anammox rates of $1.0-11.1 \mathrm{nmol} \mathrm{N}_{2} \mathrm{~L}^{-1} \mathrm{~d}^{-1}$ from our ${ }^{15} \mathrm{NH}_{4}^{+}$treatments are within the lower end of the range previously reported in other oxygen-deficient zones (Table 3). The low anammox rates at Sta. 1 correspond well

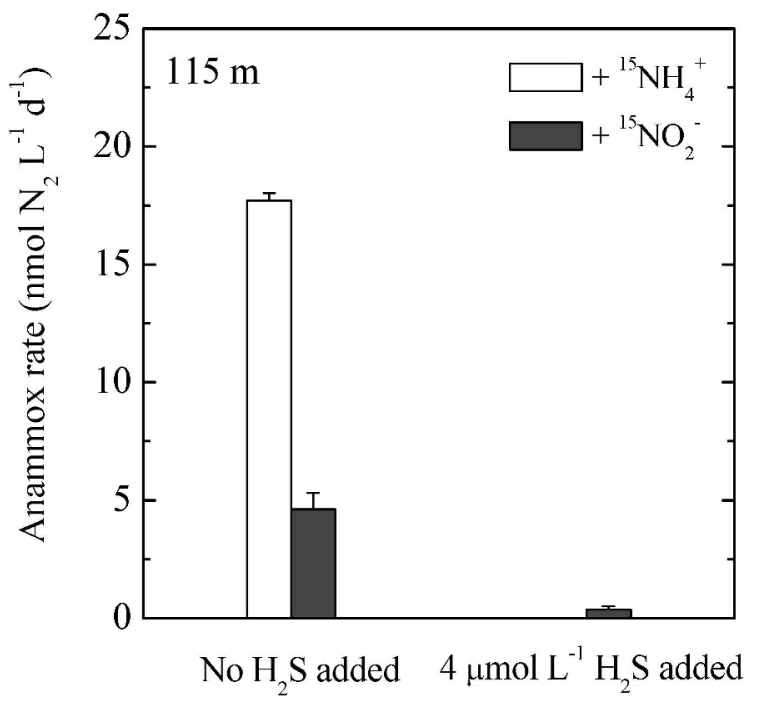

Fig. 5. Rates of anammox in anoxic water incubations without and with additions of $4 \mu \mathrm{mol} \mathrm{L}-1 \mathrm{H}_{2} \mathrm{~S}$. Water for the incubations was sampled at $115 \mathrm{~m}$ at Sta. 2, 20 August.

with the Black Sea generally being characterized as an oligotrophic system (Sorokin 2002).

Anammox rates peaked in the vicinity of the sharp interface between nitrate and ammonium at $100 \mathrm{~m}$ (Fig. 2). This is consistent with observations from the central western basin, where potential anammox activity and abundance of anammox bacteria and specific ladderane lipids peaked in the zone of nitrite and ammonium disappearance (Kuypers et al. 2003). Our observations confirm the view of anammox in the Black Sea as an interface process fueled mainly by ammonium transported from the deeper basin (Kuypers et al. 2006). This contrasts with the results from the Pacific oxygen minimum zones (OMZs) where ammonium is supplied locally during mineralization (Dalsgaard et al. 2003; Thamdrup et al. 2006). Our results were also in good agreement with rates derived from the ammonium distribution through a transport-reaction model assuming vertical eddy diffusion as the main mechanism of transport (Lam et al. 2007). This model indicated a consumption of ammonium between 90- and $102-\mathrm{m}$ depth, with a maximum rate of $14 \mathrm{nmol} \mathrm{L}^{-1} \mathrm{~d}^{-1}$ at $100-\mathrm{m}$ depth, similar to the maximum of $11 \mathrm{nmol} \mathrm{N}_{2}$ $\mathrm{L}^{-1} \mathrm{~d}^{-1}$ that we measured at this depth. The depthintegrated modeled rate for this interval was $75 \mu \mathrm{mol}$ $\mathrm{m}^{-2} \mathrm{~d}^{-1}$, which was also comparable to the integrated measured rates of anammox between 95 and $105 \mathrm{~m}$ of $83 \mu \mathrm{mol} \mathrm{N} \mathrm{N}_{2} \mathrm{~m}^{-2} \mathrm{~d}^{-1}$ with ${ }^{15} \mathrm{NH}_{4}^{+}$. These rates also corresponded well with the previously modeled rate of $91 \mu \mathrm{mol} \mathrm{m} \mathrm{m}^{-2} \mathrm{~d}^{-1}$ for the suboxic zone in the central western basin of the Black Sea (Kuypers et al. 2003). The close agreement between the measured rate of ammonium oxidation and the net rate of ammonium consumption obtained from modeling the ammonium distribution supports that ammonium is supplied mainly from outside the suboxic zone rather than by a local source. The agreement between the two independently obtained rates further suggests that anammox in our incubations was not 
Table 3. Summary of anammox rates from various studies of oxygen-deficient zones.

\begin{tabular}{lccc}
\hline \hline & $\begin{array}{c}\text { Anammox } \\
\left(\mathrm{nmol} \mathrm{N} \mathrm{L}^{-1} \mathrm{~d}^{-1}\right)^{*}\end{array}$ & $\begin{array}{c}\text { Denitrification } \\
\left(\mathrm{nmol} \mathrm{N}_{2} \mathrm{~L}^{-1} \mathrm{~d}^{-1}\right) \dagger\end{array}$ & Reference \\
\hline Off northern Chile & $2-17$ & Not detected & (Thamdrup et al. 2006) \\
Off Peru & $0-164$ & Not detected & (Hamersley et al. 2007) \\
Off Namibia & $10-180$ & Not detected & (Kuypers et al. 2005) \\
Golfo Dulce 2001 & $72-600$ & Not detected & (Dalsgaard et al. 2003) \\
Golfo Dulce 2003 & 15 & Not detected & (Jensen 2006) \\
Black Sea & $1-11.1$ & This study & \\
\hline
\end{tabular}

\footnotetext{
* All rates from ${ }^{15} \mathrm{NH}_{4}^{+}$incubations.
}

$\uparrow$ Rate from ${ }^{15} \mathrm{NO}_{3}^{-}$incubations.

substantially enhanced by the addition of $5 \mu \mathrm{mol} \mathrm{L} \mathrm{L}^{-1}$ of ${ }^{15} \mathrm{NH}_{4}^{+}$. Likewise, the exclusion of oxygen during the incubations should have little effect. Oxygen was not detected deeper than $97 \mathrm{~m}$, and the in situ oxygen concentration at $95 \mathrm{~m}$ was $2.5 \mu \mathrm{mol} \mathrm{L}-1$, which according to our results (Fig. 4) would reduce the rate at this depth rate by $\sim 15 \%$ and affect the integrated rates only marginally. The derivation of rates based on the vertical gradients does not take into account horizontal advection, which may contribute to the zonation in the Black Sea (Sorokin 2002; Konovalov et al. 2003), but has not yet been quantified in the central part of the basin. With this reservation, the correspondence between the modeled and measured rates indicates that our ${ }^{15} \mathrm{NH}_{4}^{+}$amendments may to a certain degree reflect in situ activity of anammox bacteria. This is in agreement with the results from the Namibian and Chilean OMZs, whereas it contrasts with findings from Golfo Dulce, where ammonium addition stimulated anammox rates two- to fourfold (Dalsgaard et al. 2003; Kuypers et al. 2005; Thamdrup et al. 2006). In the case of the Black Sea, the result can be rationalized by the observation that anammox in the suboxic zone as a whole appeared limited by $\mathrm{NO}_{x}^{-}$rather than $\mathrm{NH}_{4}^{+}$. Thus, modeled rates of $\mathrm{NO}_{x}^{-}$consumption were only about half the ammonium consumption rates, which indicates that an internal nitrification process supplies anammox with substrate (Lam et al. 2007).

Several lines of evidence presented by Lam and coworkers (2007) suggest that nitrification was active in the suboxic zone and closely coupled to anammox. Thus, the authors observed an oxidation of ammonium to nitrite in incubations with ${ }^{15} \mathrm{NH}_{4}^{+}$and ${ }^{14} \mathrm{NO}_{2}^{-}$. This oxidation was inhibited by the ammonium mono-oxygenase (AMO) inhibitor ATU and stimulated by low levels of oxygen, and both the abundance of gammaproteobacterial ammonium oxidizers and their expression of the AMO gene amo $A$ peaked around 100-m depth at Sta. 1 (Lam et al. 2007). This was the depth where the production of ${ }^{15} \mathrm{~N}^{15} \mathrm{~N}$ from ${ }^{15} \mathrm{NH}_{4}^{+}$was observed, which was best explained by close coupling of ammonium oxidation to nitrite with anammox in the presence of a very small nitrite pool. Consistent with this, we observed no ${ }^{15} \mathrm{~N}^{15} \mathrm{~N}$ production in the incubations with ${ }^{15} \mathrm{NH}_{4}^{+}$and ${ }^{14} \mathrm{NO}_{2}^{-}$, which were part of the oxygen experiment carried out with water from 100$\mathrm{m}$ depth $1 \mathrm{~d}$ later. In this case, the larger nitrite pool would efficiently trap the ${ }^{15} \mathrm{NO}_{2}^{-}$generated through nitrification. A large production of $15 \mathrm{~N}^{15} \mathrm{~N}$ was also observed at $105 \mathrm{~m}$ at Sta. 2 where it may be explained by the same mechanism. We have no information about nitrification at this station, however.

Denitrification-Although our ${ }^{15} \mathrm{~N}$-labeling experiments covered the whole zone of nitrate decrease into the suboxic zone, there were no indications of any nitrate or nitrite reduction to $\mathrm{N}_{2}$ by heterotrophic denitrification at the central station (Fig. 2; Table 2). Also, addition of the simple organic acid formate did not cause any stimulation of the ${ }^{15} \mathrm{~N}^{15} \mathrm{~N}$ production (Fig. 3). There were also no indications of chemolithotrophic denitrification driven by sulfide oxidation, as nitrate and sulfide did not overlap in their vertical distribution at the central station (Fig. 2). Instead, sulfide must be oxidized by another electron acceptor (Murray et al. 1995; Oguz et al. 2001; Konovalov et al. 2003). Although we did not find any indications of chemolithotrophic denitrification driven by sulfide oxidation at the central station, denitrification may be important in other regions of the Black Sea, where sulfide and nitrate/nitrite may meet in a common reaction interface or where lateral interleaving of nitrate-containing water masses into layers of anoxic deep waters can be perceived as mechanisms that promote chemolithotrophic denitrification. The potential for chemolithotrophic denitrification has previously been demonstrated in water samples from the oxic-anoxic interface of the Black Sea (Sorokin 1964).

The absence of denitrification in our incubations is similar to results from the oxygen-deficient zones off Namibia and northern Chile (Kuypers et al. 2005; Thamdrup et al. 2006). Intriguingly, water column denitrification has been unambiguously detected together with anammox on only one occasion, in Golfo Dulce, where anammox rates were very high compared to our rates and those from Chile and Namibia (Table 3). A study of anammox and denitrification in the water column of Golfo Dulce conducted $2 \mathrm{yr}$ after the first study showed no evidence of denitrification, while anammox rates were low compared to the first visit (Table 3). Thus, even in Golfo Dulce, the co-occurrence of the two processes may have been an ephemeral phenomenon, which leaves sediments as the only marine setting where the two processes are consistently found together (cf. Dalsgaard et al. 2005). An explanation for this variability remains to be found, but the dominance of anammox in the water column may be related to the differential sensitivity to oxygen of the two 
processes, as suggested in the Namibian case (Kuypers et al. 2005) and emphasized by our results (Fig. 4; discussion below). Accurate determinations of oxygen concentrations in suboxic waters are certainly a key point for a deeper understanding of the regulation of microbial processes in these systems.

A recent study of the dissimilatory nitrite reductase genes nirK and nirS from the suboxic zone of the central western Black Sea indicated the presence of denitrifiers (Oakley et al. 2007). The diversity was conspicuously low, however, and resembled that of the location off northern Chile, where anammox also dominated over denitrification in incubation experiments (Castro-González et al. 2005; Thamdrup et al. 2006). This led the authors to suggest that the depauperate denitrifier community in the Black Sea resulted from strong competition with anammox bacteria and possibly other nitrate and nitrite consumers.

Is formate a potential substrate for marine anammox bacteria? - The ability of anammox bacteria to reduce nitrate to nitrite coupled to the oxidation of simple organics including formate has been demonstrated in anammoxenrichment cultures from wastewater (Güven et al. 2005; Kartal et al. 2007b). In both studies, the biochemical mechanisms of nitrite reduction remain unclear. Recently, Kartal and coworkers (2007a) found that purified cells of "Candidatus Kuenenia stuttgartiensis" are able to oxidize formate during the reduction of ${ }^{15} \mathrm{~N}$-labeled nitrate to ${ }^{15} \mathrm{~N}^{15} \mathrm{~N}$. It was shown by following the ${ }^{15} \mathrm{~N}$ label through nitrite and ammonium pools that the anammox bacterium reduces nitrate to ammonium via dissimilatory nitrate and nitrite reduction, and subsequently, converts ammonium and nitrite into $\mathrm{N}_{2}$. Also, in samples from the oxygendeficient zone off Namibia, where only anammox produced ${ }^{14} \mathrm{~N}^{15} \mathrm{~N}$ from ${ }^{15} \mathrm{NO}_{3}^{-}, 10 \%$ of the reduced ${ }^{15} \mathrm{NO}_{3}^{-}$was found in the pool of ${ }^{15} \mathrm{NH}_{4}^{+}$(Kartal et al. 2007a). This indicates that dissimilatory nitrate reduction to ammonium was a source of ammonium for the anammox bacteria in these waters.

Because denitrification from nitrate or nitrite was not detected during our study, the production of only ${ }^{14} \mathrm{~N}^{15} \mathrm{~N}$ in the ${ }^{15} \mathrm{NO}_{3}^{-}$incubations with or without ${ }^{14} \mathrm{NH}_{4}^{+}$ indicates either that anammox is coupled to the reduction of nitrate to nitrite by nitrate-reducing bacteria or that anammox bacteria themselves can utilize $\mathrm{NO}_{3}^{-}$as an electron acceptor while oxidizing organic matter. However, our data provide no indications of formate oxidation by anammox bacteria in the central Black Sea, as there were no differences in ${ }^{14} \mathrm{~N}^{15} \mathrm{~N}$ by anammox with or without formate (Fig. 3; Table 2), and no production of ${ }^{15} \mathrm{NH}_{4}^{+}$ was observed. As off Namibia, no production of ${ }^{15} \mathrm{~N}^{15} \mathrm{~N}$ was detected during our incubations (Fig. 3; Table 3). Assuming that $10 \%$ of the ${ }^{15} \mathrm{NO}_{3}^{-}$reduced due to anammox is found in the pool of ${ }^{15} \mathrm{NH}_{4}^{+}$, as off Namibia, the observed ${ }^{14} \mathrm{~N}^{15} \mathrm{~N}$ production rate of $1.7 \pm 0.2 \mathrm{nmol} \mathrm{N}_{2}$ $\mathrm{L}^{-1} \mathrm{~d}^{-1}$ in the incubation with formate corresponds to a production of $\sim 0.2 \mathrm{nmol} \mathrm{L}-115 \mathrm{NH}_{4}^{+}$during the $48 \mathrm{~h}$ of incubation, which is below the detection limit for ${ }^{15} \mathrm{NH}_{4}^{+}$. Thus, while our data provide no evidence for formate utilization by anammox bacteria, such utilization could have been hidden. Alternatively, the lack of any effect of formate on anammox activity may also reflect that the anammox bacteria are already saturated by formate. Fatty

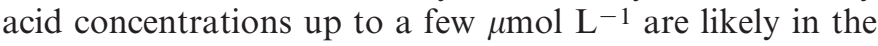
chemocline (Albert et al. 1995).

Sensitivity of anammox toward oxygen-Although anammox activity was affected by ambient oxygen, causing a decrease in rates, our results demonstrate that anammox bacteria can be active at low levels of oxygen, while anammox activity was completely inhibited at ambient concentrations of oxygen as high as 13-14 $\mu \mathrm{mol} \mathrm{L^{-1 }}$ (Fig. 4). After $\sim 30 \mathrm{~h}$ of incubation, the inhibition of anammox was slightly reduced, which is possibly linked to a slight decrease in $\mathrm{O}_{2}$, triggering the onset of ${ }^{14} \mathrm{~N}^{15} \mathrm{~N}$ production by anammox (data not shown). ATU was added to one of the oxic ${ }^{15} \mathrm{NH}_{4}^{+}$incubations to exclude a potential contribution to ${ }^{14} \mathrm{~N}^{15} \mathrm{~N}$ production from combined nitrification-denitrification pathway, which would complicate the interpretation of the ${ }^{15} \mathrm{NH}_{4}^{+}$incubations. Addition of ATU did not decrease ${ }^{14} \mathrm{~N}^{15} \mathrm{~N}$ production, which excluded such a contribution (Fig. 4). The absence of detectable ${ }^{15} \mathrm{~N}^{15} \mathrm{~N}$ production from ${ }^{15} \mathrm{NO}_{2}^{-}$ further demonstrated the insignificance of denitrification (Fig. 3).

The influence of oxygen on anammox activity in enrichment cultures has previously been investigated both in batch experiments and in bioreactors (van de Graaf et al. 1996; Strous et al. 1997; Jetten et al. 2001). The metabolism of cultivated anammox bacteria was inhibited completely but reversibly by exposure to $1 \mu \mathrm{mol} \mathrm{L}-1$ of oxygen (Strous et al. 1997; Jetten et al. 2001), which caused a reduction in anammox rates by only $\sim 7-8 \%$ in our incubations (Fig. 4). The difference between marine and cultured anammox organisms has previously been supported by phylogenetic analysis, showing that members of "Candidatus Scalindua" found in the suboxic zone of the Black Sea are only distantly related to the members of "Candidatus Brocadia" studied in the bioreactors ( $<85 \%$ sequence similarity) (Strous et al. 1999; Strous 2000; Kuypers et al. 2005, 2006).

Our results emphasize that the marine anammox process is not constrained to fully anoxic environments, which has important implications because it substantially expands the volume of the oceans in which anammox is likely to be active, now including not only the core of the oxygen minimum zones where $\mathrm{O}_{2}$ is not detectable by Winkler techniques $\left(\leq \sim 2 \mu \mathrm{mol} \mathrm{L} \mathrm{L}^{-1}\right)$ but also the suboxic layers surrounding this core (Helly and Levin 2004; Li et al. 2006). Laboratory experiments and high-quality oceanic oxygen and nitrite data suggest that denitrification is active only at $\leq 2-4 \mu \mathrm{mol} \mathrm{L}-1 \quad \mathrm{O}_{2}$ (Devol 1978; Codispoti et al. 2005). Thus, anammox may be operative in a larger water volume than denitrification, which further emphasizes the importance of anammox for the marine nitrogen cycle. Our observation of anammox activity at low oxygen levels also extends the significance of previous findings of anammox bacteria and potential anammox activity at low oxygen concentrations under the highly dynamic conditions off Namibia (Kuypers et al. 2005). Over the Namibian shelf, 
anoxic ${ }^{15} \mathrm{~N}$ tracer incubations, ladderane-lipid distributions, and FISH with probes specific for anammox bacteria indicated that active anammox bacteria were abundant at depths where in situ oxygen concentrations varied between 0.3 and $9 \mu \mathrm{mol} \mathrm{L}^{-1}$ (Kuypers et al. 2005). The authors hypothesized that anammox was also active in situ, possibly protected from oxygen inside marine snow aggregates that were abundant in the Namibian shelf water. Alternatively, as activity measurements were done in anoxic incubations after purging out the ambient oxygen, the anammox bacteria may be dormant during exposure to oxygen in situ and regain their activity immediately after reintroducing anoxia in the incubations (Kuypers et al. 2005). Our results clearly demonstrate that anammox can be active at the ambient oxygen levels, too. However, anammox rates determined in anoxic incubation experiments may be stimulated by $\sim 30-50 \%$ in environments with suboxic conditions $\left(\left[\mathrm{O}_{2}\right]=\sim 3-10 \mu \mathrm{mol} \mathrm{L}^{-1}\right)$ (Fig. 4). As mentioned previously, the agreement between modeled and measured rates indicates that our incubation experiment reflects natural conditions. Our finding of anammox at low oxygen concentrations also opens the possibility for coupling to nitrification as a source of nitrite (Lam et al. 2007), similar to the observations in wastewater treatment systems (Third et al. 2001).

Inhibition of anammox by sulfide-Sulfide had an inhibitory effect on anammox activity (Fig. 5). This indicates that the process may be of minor importance in systems where steep gradients of oxygen and sulfide form a common reaction front, as in Mariager Fjord, where there was no evidence for the anammox process in the vicinity of chemocline, which separates oxygenated and highly sulfidic waters during prolonged stratification periods (Jensen 2006). Instead, lithotrophic denitrification was found to be the dominant $\mathrm{N}_{2}$-producing process in Mariager Fjord.

The sensitivity to low sulfide levels suggests that sulfide may also be an important regulator for anammox in sediments, where sulfide has previously been shown to cause an irreversible inhibition of aerobic ammonium oxidation (Joye and Hollibaugh 1995; Sears et al. 2004; Dollhopf et al. 2005).

In summary, our results confirm the importance of anammox as a sink for fixed nitrogen in the suboxic zone of the Black Sea and identify oxygen and sulfide concentrations as important controls on marine anammox. The microaerotolerant lifestyle of anammox bacteria, which thrive in water masses with low levels of oxygen up to $\sim 10 \mu \mathrm{mol} \mathrm{L}-1$, supports the important role of anammox on a global scale as the areas favorable for anammox widen. Thus, active marine anammox bacteria may be found in environments with fluctuating oxygen concentrations as in the oxygen-deficient waters of coastal upwelling areas or oxic-anoxic interfaces such as commonly found in sediments or microenvironments within aggregates. Any prolonged oxygen effect on anammox bacteria needs to be explored. The inhibitory effect of sulfide on anammox constrains the vertical distribution of active anammox bacteria to nonsulfidic water layers. At favorable oxygen and sulfide levels, interactions with nitrifyers, denitrifyers, and possibly other bacteria are important.

\section{References}

Albert, D. B., C. Taylor, and C. S. Martens. 1995. Sulfate reduction rates and low molecular weight fatty acid concentrations in the water column and surficial sediments of the Black Sea. Deep-Sea Res. I 42: 1239-1260.

BédArd, C., AND R. KNowles. 1989. Physiology, biochemistry, and specific inhibitors of $\mathrm{CH}_{4}, \mathrm{NH}_{4}^{+}$, and $\mathrm{CO}$ oxidation by methanotrophs and nitrifiers. Microbiol. Rev. 53: 68-84.

Braman, R. S., and S. A. Hendrix. 1989. Nanogram nitrite and nitrate determination in environmental and biological materials by vanadium(III) reduction with chemiluminescence detection. Anal. Chem. 61: 2715-2718.

Castro-González, M., G. Braker, L. Farias, and O. Ulloa. 2005. Communities of nirS-type denitrifiers in the water column of the oxygen minimum zone in the eastern South Pacific. Environ. Microbiol. 7: 1298-1306.

Cline, J. D. 1969. Spectrophotometric determination of hydrogen sulfide in natural waters. Limnol. Oceanogr. 14: 454458.

Codispoti, L. A., G. E. Friederich, J. W. Murray, and C. M. SAкамото. 1991. Chemical variability in the Black Sea: Implications of continuous vertical profiles that penetrated the oxic/anoxic interface. Deep-Sea Res. 38: S691-S710.

, T. Yoshinari, And A. H. Devol. 2005. Suboxic respiration in the oceanic water column, p. 225-247. In P. B. Williams [ed.], Respiration in aquatic ecosystems. Oxford University Press.

- AND OTHERS. 2001. The oceanic fixed nitrogen and nitrous oxide budgets: Moving targets as we enter the anthropocene? Sci. Mar. 65: 85-105.

Dalsgaard, T., D. E. Canfield, J. Petersen, B. Thamdrup, and J. Acuna-Gonzalez. 2003. $\mathrm{N}_{2}$ production by the anammox reaction in the anoxic water column of Golfo Dulce, Costa Rica. Nature 422: 606-608.

—, AND B. Thamdrup. 2002. Factors controlling anaerobic ammonium oxidation with nitrite in marine sediments. Appl. Environ. Microbiol. 68: 3802-3808.

, B. Thamdrup, and D. E. CAnfield. 2005. Anaerobic ammonium oxidation (anammox) in the marine environment Res. Microbiol. 156: 457-464.

Dapena-Mora, A., I. Fernández, J. L. Campos, A. MosqueraCorral, R. Méndez, and M. S. M. Jetten. 2007. Evaluation of activity and inhibition effects on anammox process by batch tests based on the nitrogen gas production. Enzyme Microb. Technol. 40: 859-865.

Devol, A. 1978. Bacterial oxygen uptake kinetics as related to biological processes in oxygen deficient zones of the ocean. Deep-Sea Res. 25: 137-146.

Devol, A. H. 2003. Solution to a marine mystery. Nature 422: 575-576.

Dollhopf, S. L., J. Hyun, A. C. Smith, H. J. Adams, S. Obrien, AND J. E. KostKA. 2005. Quantification of ammonia-oxidizing bacteria and factors controlling nitrification in salt marsh sediments. Appl. Environ. Microbiol. 71: 240-246.

Friederich, G. E., ANd L. A. Codispoti. 1987. An analysis of continuous vertical nutrient profiles taken during a coldanomaly off Peru. Deep-Sea Res. Pt. I Oceanogr. Res. Pap. 34: 1049-1065.

GrasshofF, K. 1983. Determination of nitrite. In K. Kremling [ed.], Methods in seawater analyses. Wiley-VCH.

Güven, D., AND others. 2005. Propionate oxidation by and methanol inhibition of anaerobic ammonium-oxidizing bacteria. Appl. Environ. Microbiol. 71: 1066-1071. 
Hall, G. H. 1984. Measurement of nitrification rates in lake sediments: Comparison of the nitrification inhibitors nitrapyrin and allylthiourea. Microb. Ecol. 10: 25-36.

- AND C. JEFFrIES. 1984. The contribution of nitrification in the water column and profundal sediments to the total oxygen deficit of the hypolimmnion of a mesotrophic lake. Microb. Ecol. 10: $37-46$.

Hamersley, M. R., AND others. 2007. Anaerobic ammonium oxidation in the Peruvian oxygen minimum zone. Limnol. Oceanogr. 52: 923-933.

Helly, J. J., AND L. A. Levin. 2004. Global distribution of naturally occurring marine hypoxia on continental margins. Deep-Sea Res. Pt I Oceanogr. Res. Pap. 51: 1159-1168.

Holmes, R. M., A. Аminot, R. Kerouel, A. Hooker, and B. J. PETERSON. 1999. A simple and precise method for measuring ammonium in marine and freshwater ecosystems. Can. J. Fish Aqaut. Sci. 56: 1801-1808.

Hulth, S., R. C. Aller, and F. Gilbert. 1999. Coupled anoxic nitrification/manganese reduction in marine sediments. Geochim. Cosmochim. Acta 63: 49-66.

Jensen, M. M. 2006. Anaerobic ammonium oxidation in the marine nitrogen cycle, Ph.D. thesis, Univ. of Southern Denmark.

- B. Thamdrup, and T. Dalsgand. 2007. Effects of specific inhibitors on anammox and denitrification in marine sediment. Appl. Environ. Microbiol. 73: 3151-3158.

Jetten, M. S. M., M. Wagner, J. Fuerst, M. van Loosdrecht, G. Kuenen, And M. Strous. 2001. Microbiology and application of the anaerobic ammonium oxidation ("anammox") process. Curr. Opin. Biotechnol. 12: 283-288.

Joye, S. B., And J. T. Hollibaugh. 1995. Influence of sulfide inhibition of nitrification on nitrogen regeneration in sediments. Science 270: 623-625.

Kartal, B., AND others. 2007a. Anammox bacteria disguised as denitrifyers: Nitrate reduction to dinitrogen gas via nitrate and ammonium. Environ. Microbiol. 9: 635-642.

- 2007b. Candidatus "Anammoxoglobus propionicus" a new propionate oxidizing species of anaerobic ammonium oxidizing bacteria. Syst. Appl. Microbiol. 30: 39-49.

Konovalov, S. K., AND others. 2003. Lateral injection of oxygen with the Bosporus plume-Fingers of oxidizing potential in the Black Sea. Limnol. Oceanogr. 48: 2369-2376.

Kuypers, M. M. M., G. Lavik, And B. Thamdrup. 2006. Anaerobic ammonium oxidation in the marine environment, p. 311-332. In L. N. Neretin [ed.], Past and present water column anoxia. NATO Sciences Series. IV. Earth and Environmental Sciences. Springer.

- AND OTHERS. 2005. Massive nitrogen loss from the Benguela upwelling system through anaerobic ammonium oxidation. Proc. Natl. Acad. Sci. USA 102: 6478-6483.

$\longrightarrow$, AND OTHERS. 2003. Anaerobic ammonium oxidation by anammox bacteria in the Black Sea. Nature 422: 608-611.

LAM, P., AND OTHERS. 2007. Linking crenarchaeal and bacterial nitrification to anammox in the Black Sea. Proc. Natl. Acad. Sci. USA 104: 7104-7109.

Li, Y., L. Menviel, and T. Peng. 2006. Nitrate deficits by nitrification and denitrification processes in the Indian Ocean. Deep-Sea Res. I 53: 94-100.

Luther, G. W., B. Sundby, B. L. Lewis, P. J. Brendel, And N. SilverberG. 1997. Interactions of manganese with the nitrogen cycle: Alternative pathways to dinitrogen. Geochim. Cosmochim. Acta 61: 4043-4052.

Mulder, A., A. A. Vandegraaf, L. A. Robertson, and J. G. Kuenen. 1995. Anaerobic Ammonium Oxidation Discovered in a Denitrifying Fluidized-Bed Reactor. FEMS Microbiol. Ecol. 16: 177-183.
Murray, J. W., L. A. Codispoti, and G. E. Friederich. 1995. Oxidation-reduction environments. The suboxic zone in the Black Sea, p. 157-176. In J. J. Morgan [ed.], Aquatic chemistry, interfacial and interspecies processes: Advances in chemistry series 244. Am. Chem. Soc.

-, AND E. Yakushev. 2006. The suboxic transition zone in the Black Sea, p. 105-138. In L. N. Neretin [ed.], Past and present water column anoxia. NATO Sciences Series. IV. Earth and Environmental Sciences. Springer.

—, AND OTHERS. 1989. Unexpected changes in the oxic/anoxic interface in the Black Sea. Nature 338: 411-412.

Oakley, B. B., C. A. Francis, K. J. Roberts, C. A. Fuchsman, S. Srinivasan, and J. T. Staley. 2007. Analysis of nitrite reductase (nirK and nir $S$ ) genes and cultivation reveal depauperate community of denitrifying bacteria in the Black Sea suboxic zone. Environ. Microbiol. 9: 118-130.

Oguz, T., J. W. Murray, and A. E. Callahan. 2001. Modeling redox cycling across the suboxic-anoxic interface zone in the Black Sea. Deep-Sea Res. I 48: 761-787.

Özsoy, E., AND Ü. ÜnLÜATA. 1997. Oceanography of the Black Sea: A review of some recent results. Earth-Sci. Rev. 42: 231-272.

Risgaard-Petersen, N., S. Rysgaard, and N. P. Revsbech. 1995. Combined microdiffusion-hypobromite oxidation method for determining nitrogen-15 isotope in ammonium. Soil Sci. Soc. Am. J. 59: 1077-1080.

Schmid, M., AND others. 2003. Candidatus "Scalindua brodae," sp. nov., Candidatus "Scalindua wagneri," sp. nov., two new species of anaerobic ammonium oxidizing bacteria. Syst. Appl. Microbiol. 26: 529-538.

Sears, K., J. E. Alleman, J. L. Barnard, and J. A. Oleszkiewicz. 2004. Impact of reduced sulfur components on active and resting ammonia oxidizers. J. Ind. Microbiol. Biotechnol. 31: 369-378.

Sinninghe Damsté, J. S., AND others. 2002. Linearly concatenated cyclobutane lipids form a dense bacterial membrane. Nature 419: 708-712.

Sorokin, Y. I. 1964. On the primary production and bacterial activities in the Black Sea. J. Cons. Int. Explor. Mer. 29: 41-60.

. 2002. The Black Sea: Ecology and oceanography. Backhuys.

Strous, M. 2000. Microbiology of anaerobic ammonium oxidation, Ph.D. thesis, Technische Univ. Delft.

, E. van Gerven, J. G. Kuenen, and M. Jetten. 1997. Effects of aerobic and microaerobic conditions on anaerobic ammonium-oxidizing (anammox) sludge. Appl. Environ. Microbiol. 63: 2446-2448.

- AND OTHERs. 1999. Missing lithotroph identified as new planctomycete. Nature 400: 446-449.

$\longrightarrow$, AND OTHERs. 2006. Deciphering the evolution and metabolism of an anammox bacterium from a community genome. Nature 440: 790-794.

Tebo, B. M. 1991. Manganese(II) oxidation in the suboxic zone of the Black Sea. Deep-Sea Res. 38: S883-S905.

Thamdrup, B., And T. Dalsgandd. 2000. The fate of ammonium in anoxic manganese oxide-rich marine sediment. Geochim. Cosmochim. Acta 64: 4157-4164.

—, AND T. DalsgaArd. 2002. Production of $\mathrm{N}_{2}$ through anaerobic ammonium oxidation coupled to nitrate reduction in marine sediments. Appl. Environ. Microbiol. 68: 1312-1318.

- T. Dalsgaard, M. M. Jensen, O. Ulloa, L. Farias, and R. EsCribano. 2006. Anaerobic ammonium oxidation in the oxygen-deficient waters off northern Chile. Limnol. Oceanogr. 51: 2145-2156. 
Third, K. A., A. O. Sliekers, J. G. Kuenen, and M. S. M. JETTEN. 2001. The CANON system (completely autotrophic nitrogen-removal over nitrite) under ammonium limitation: Interaction and competition between three groups of bacteria. Syst. Appl. Microbiol. 24: 588-596.

van de GraAf, A. A., P. de Bruijn, L. A. Robertson, M. S. M. Jetten, and J. G. Kuenen. 1996. Autotrophic growth of anaerobic ammonium-oxidizing micro-organisms in a fluidized bed reactor. Microbiology (UK) 142: $2187-$ 2196.
, A. Mulder, P. de Bruijn, M. Jetten, L. A. Robertson, And G. KuENEN. 1995. Anaerobic oxidation of ammonium is a biologically mediated process. Appl. Environ. Microbiol. 61: 1246-1251.

Zumft, W. G. 1997. Cell biology and molecular basis of denitrification. Microbiol. Mol. Biol. Rev. 61: 533-616.

Received: 15 December 2006 Accepted: 5 September 2007 Amended: 2 October 2007 